\title{
ON THE RELATIONSHIP OF ICE-SURFAGE TOPOGRAPHY TO BED TOPOGRAPHY ON THE SOUTH POLAR PLATEAU
}

\author{
By Edwin S. Robinson
}

\author{
(Department of Geophysics, College of Mines and Mineral Industries, University of Utah, \\ Salt Lake City, Utah, U.S.A.)
}

\begin{abstract}
Ice-surface and isopachous maps, and rock-elevation maps, were prepared for the area between the South Pole and the Horlick Mountains from seismic and gravimetric measurements. Basal shear-stress was calculated from these data and surface-slope measurements at 25 sites. The mean is 0.8 bar with an areal standard deviation of 0.5 bar. Forty-five values of average basal shear stress were computed from consecutive $30 \mathrm{~km}$. segments along flow lines. The mean is 0.4 bar with an areal standard deviation of o. I bar. These variations are too large for accurate estimates of ice-thickness variations to be made from surface-slope data alone, following Nye's suggestion that basal shear-stress be treated as constant. From theoretical considerations Nye demonstrated that surface features of wave-length less than $40 \mathrm{~km}$. should disappear within a few months unless related to bed topography. Ice and rock profiles along a $220 \mathrm{~km}$. line do not show an expected theoretical relationship. Surface-elevation measurements, repeated after a 2 yr. interval, showed the surface features with wave-lengths between 5 and $40 \mathrm{~km}$. to be essentially unchanged in amplitude and position. Hence these features are not adequately explained by existing theory.
\end{abstract}

RÉsumÉ. Sur la relation entre la topographie superficielle de la glace et celle du socle et les variations de l'épaisseur de la glace de l'Indlandsis Antarctique. Les cartes de la surface de la glace et des courbes d'égale épaisseur, et les cartes des altitudes des roches, ont été préparées entre le Pôle Sud et les Horlick Mountains sur la base des mesures sismiques et gravimétriques. La contrainte de cisaillement à la base a été calculée à partir de ces donnés et les mesures de la pente superficielle en 25 stations. La moyenne est de o,8 bar avec une déviation standard par surface de 0,5 bar. Quarante valeurs de la contrainte moyenne de cisaillement à la base ont été calculées pour des segments adjacents de $30 \mathrm{~km}$ le long des lignes d'écoulement. La moyenne est de o,4 bar avec une déviation standard par surface de $\mathrm{O}, \mathrm{I}$ bar. Ces variations sont trop grandes pour des estimations précises des variations d'épaisseur de glace à partir uniquement de la pente superficielle, suivant la suggestion de Nye que la contrainte de cisaillement à la base peut être considérée comme constante. A partir de considérations théoriques Nye a démontré que des accidents superficiels d'une longueur d'onde inférieure à $40 \mathrm{~km}$ devraient disparaître dans l'espace de quelques mois à moins d'être liés à la topographie du socle. Des profils de glace et de roches le long d'une ligne de $220 \mathrm{~km}$ ne montra point la relation théoriquement prévue. Les mesures des élévations superficielles répétées après un intervalle de deux années, montrèrent que les accidents superficiels de longueur d'onde entre 5 et $40 \mathrm{~km}$ étaient inchangés en amplitude et position. Ces accidents ne sont pas adéquatement expliqués par la théorie mentionnée.

Zusammenfassung. Das Verhältnis des Oberflächenreliefs zur Untergrundstopographie und zu Eisdickenschwankungen auf dem Südpolplateau. Aus seismischen und gravimetrischen Messungen wurden Karten der Eisoberfläche, der Eisdicke und des Felsuntergrundes für das Gebict zwischen dem Südpol und den Horlick Mountains entwickelt. Aus diesen Daten und aus Messungen der Oberflächenneigung an 25 Stellen wurde die Scherspannung am Untergrund berechnet. Der Mittelwert beträgt o,8 bar mit einer mittleren Abweichung von 0,5 bar. Aus aufeinanderfolgenden $30 \mathrm{~km}-$ Abschnitten entlang von Stromlinien wurden 45 Werte der mittleren Scherspannung am Untergrund berechnet. Der Mittelwert beträgt 0,4 bar mit einer mittleren Abweichung von o, I bar. Diese Schwankungen sind zu gross für eine zuverlässige Abschätzung der Eisdickenschwankungen allein aus Werten der Oberfächenneigung gemäss Nye's Vorschlag, nach dem die Scherspannung am Untergrund als konstant anzunehmen ist. Nye zeigte auf Grund theoretischer Überlegungen, dass Oberflächenerscheinungen mit Wellenlängen unter $40 \mathrm{~km}$ in wenigen Monaten verschwinden sollten, wenn sie nicht von der Untergrundstopographie herrühren. Eis- und Felsprofile längs einer Linie von $220 \mathrm{~km}$ Länge zeigen nicht die theoretisch erwartete Beziehung. Messungen der Oberflächenhöhe, die nach 2 Jahren wiederholt wurden, liessen keine wesentliche Änderung der Oberflächenerscheinungen mit Wellenlängen zwischen 5 und $40 \mathrm{~km}$ in Amplitude oder Lage erkennen. Diese Erscheinungen sind daher theoretisch noch nicht befriedigend erklärt.

\section{INTRODUCTION}

Various aspects of glaciology and subglacial geology were studied in an area of approximately $9 \times \mathrm{IO}^{4} \mathrm{~km} .{ }^{2}$ located between the South Pole and the Horlick Mountains. Field work was done by an oversnow traverse party along the route shown in Figure I during the I $962-63$ season. The field program included seismic, gravimetric and magnetic surveys, surfaceelevation measurements, studies of firn stratigraphy and temperature, and surface-slope measurements. This discussion is concerned with data which provide a basis for experimental examination of recently published theoretical relationships between ice-surface and bed topography. 


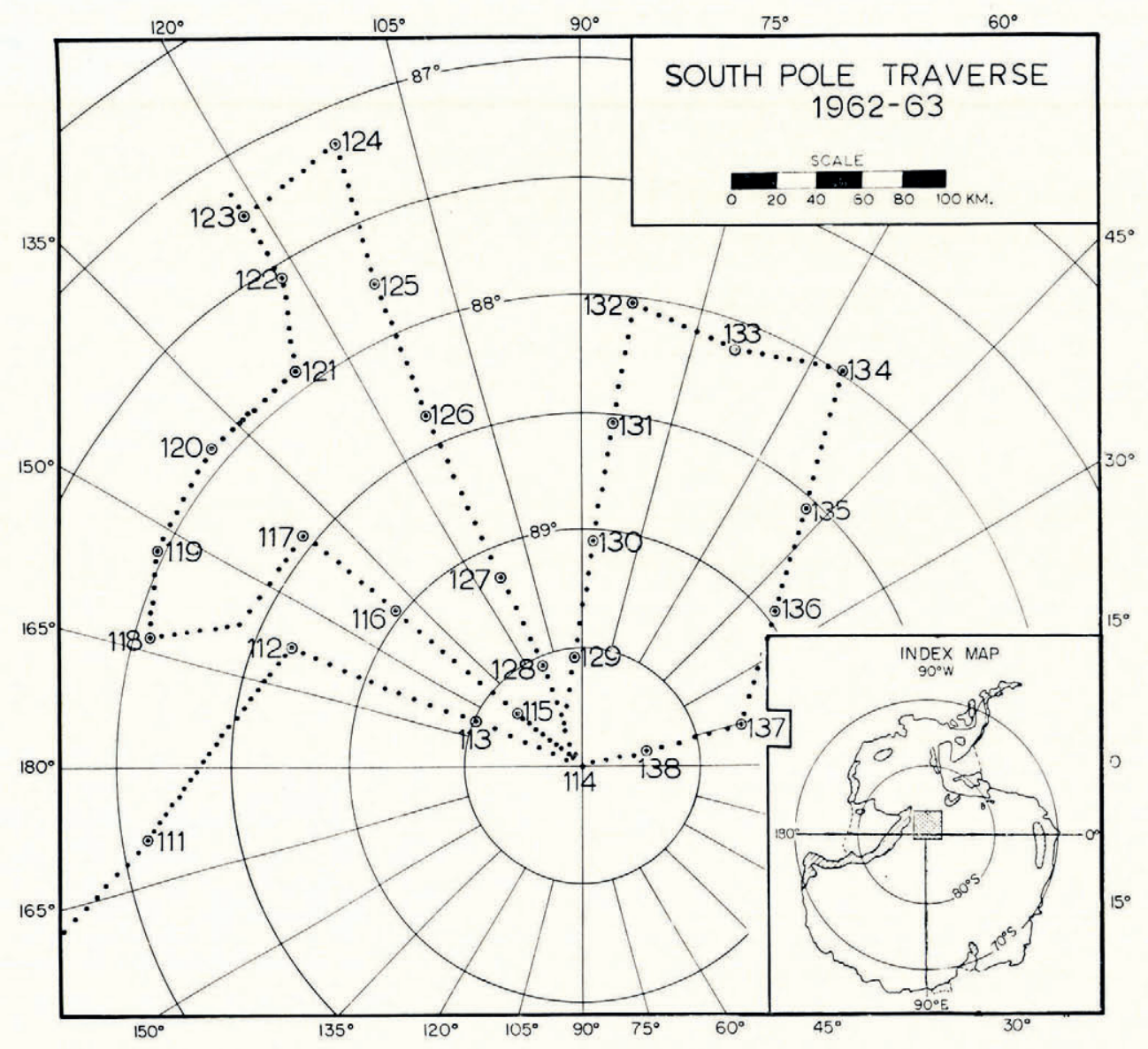

Fig. 1. Route followed by the traverse party

\section{Elevation, Seismic and Gravimetric Surveys}

Surface elevation was measured at minor stations placed at $7 \mathrm{~km}$. intervals along the traverse route (Fig. I). The interval method of barometric altimetry was used, which involved simultaneous readings of pairs of altimeters located at adjacent minor stations (Bentley, r962). Three altimeters in each of two vehicles traveling $7 \mathrm{~km}$. apart were employed. In addition, readings were made every $\mathrm{I} \cdot 5 \mathrm{~km}$. while traveling; these latter profiles were adjusted to absolute values of elevation at minor stations. A statistical study of random error and closure error for different altimeter pairs (Robinson, 1964) indicated that the absolute elevation values are accurate within $\pm 40 \mathrm{~m}$., but relative elevations along segments of less than $5^{\circ} \mathrm{km}$. are probably accurate to $\pm \mathrm{I} 0 \mathrm{~m}$.

Ice thickness was measured at major stations placed at $30-50 \mathrm{~km}$. intervals (Fig. I). Seismic reflection measurements were made, and clear reflections were identified on at least three records from each station (Fig. 2). Seismic-velocity structure in the ice sheet was determined from refraction surveys, wide-angle reflections and empirical temperature-velocity 

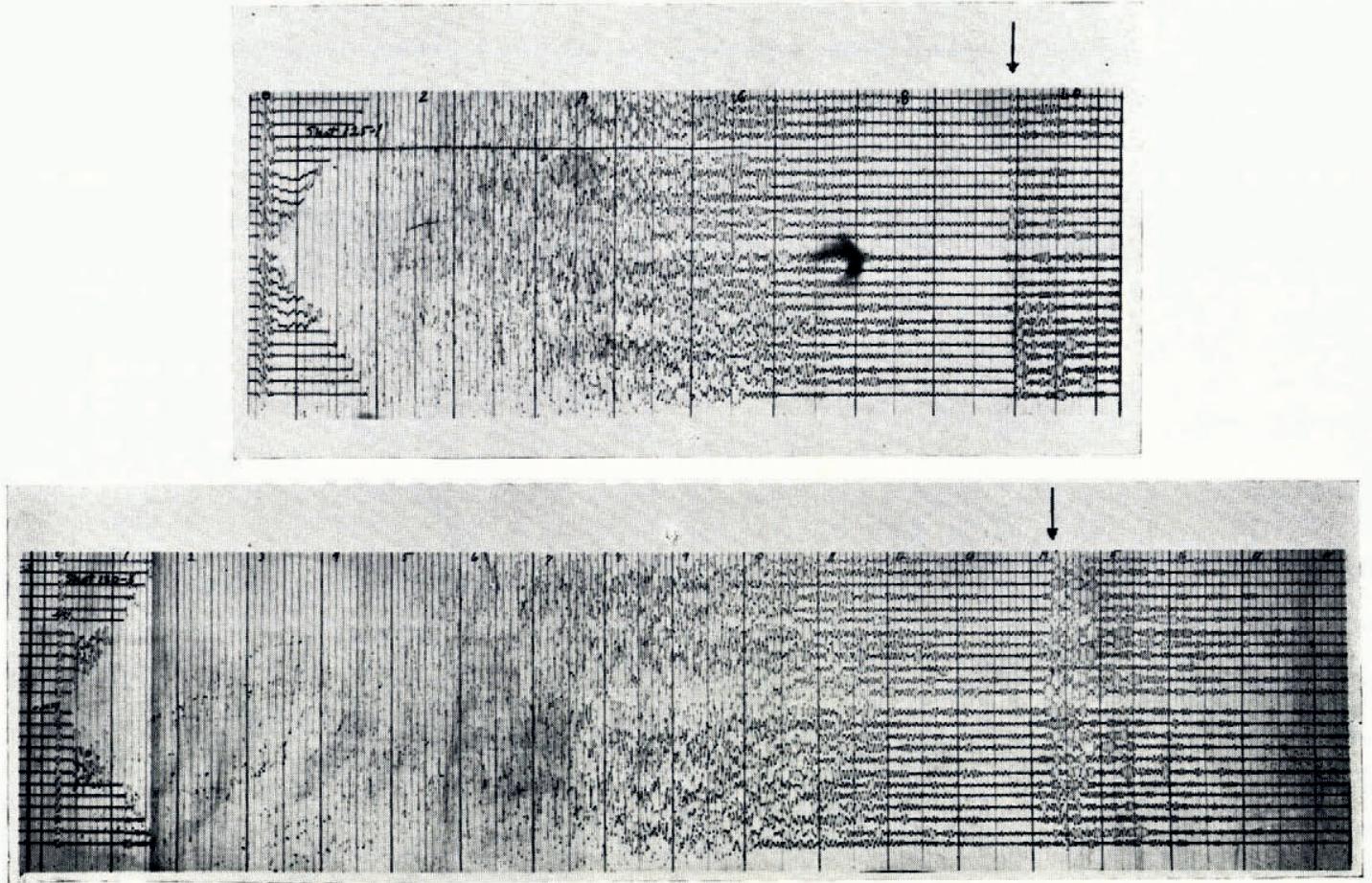

Fig. 2. Sample seismograms: (above) lat. $87^{\circ} 4^{6^{\prime}}$ S., long. $113 \cdot 4^{\circ} \mathrm{W}$; (below) lat. $89^{\circ}$ o $2^{\prime}$ S., long. $87 \cdot \mathrm{I}^{\circ} \mathrm{W}$.
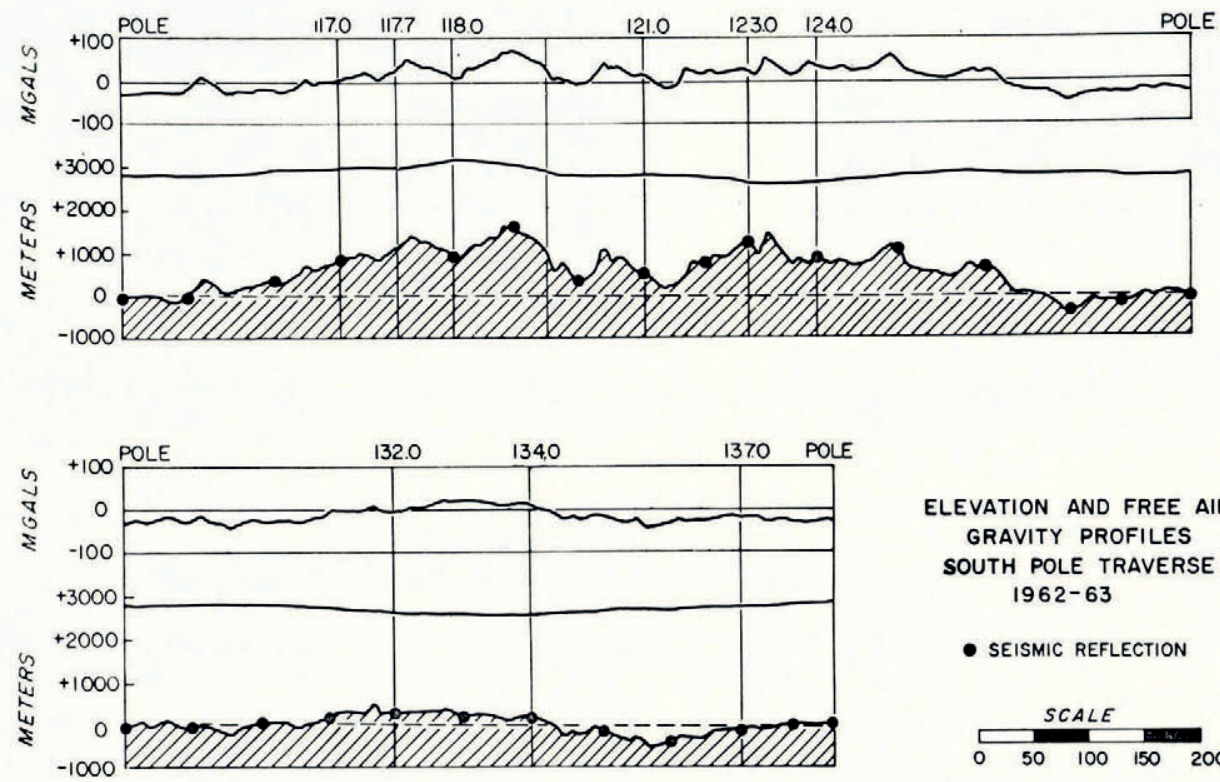

\section{ELEVATION AND FREE AIR GRAVITY PROFILES SOUTH POLE TRAVERSE 1962-63}

- SEISMIC REFLECTION

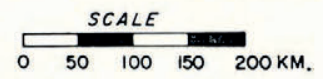

Fig. 3. Data profiles from traverse route 


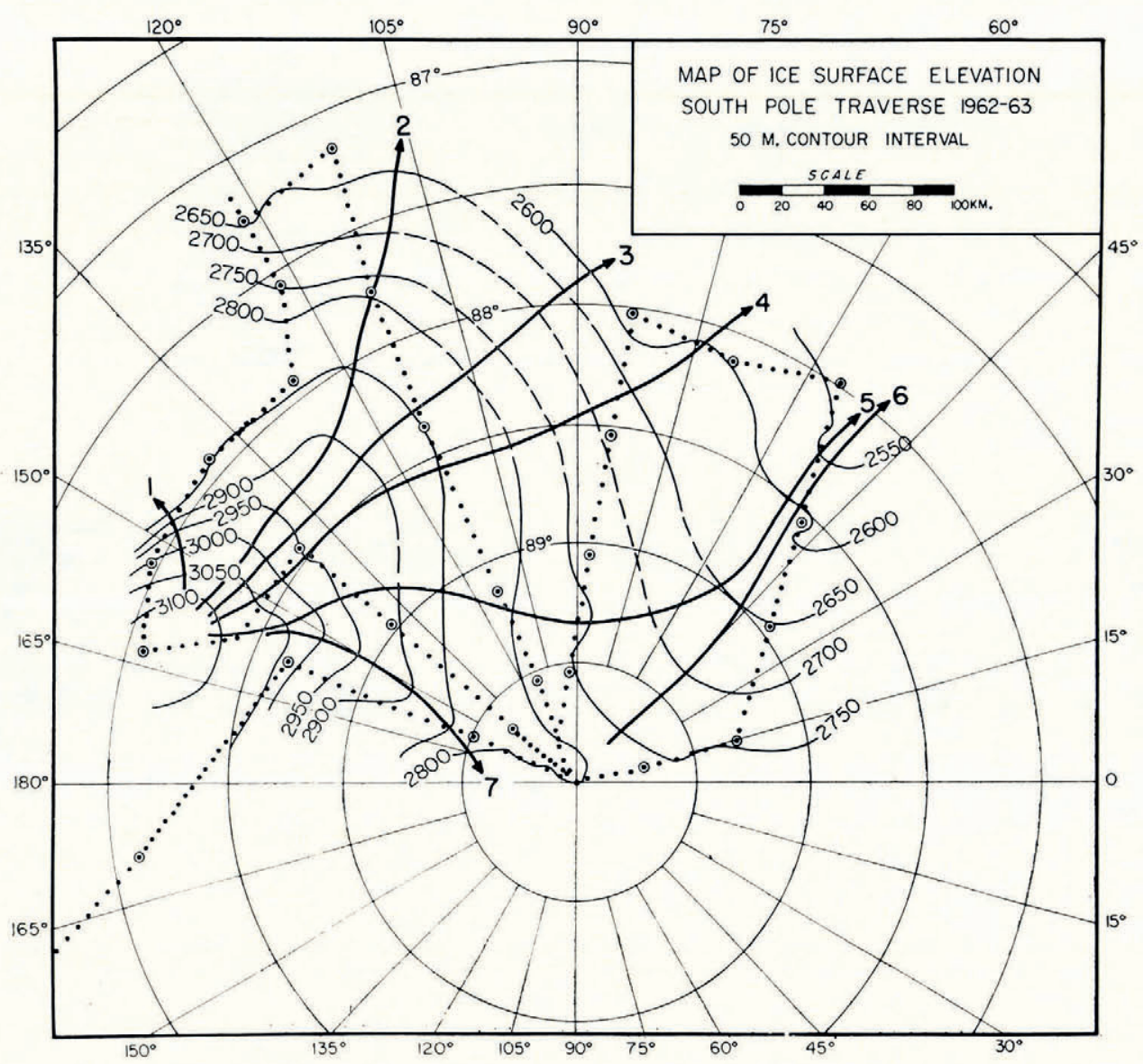

Fig. 4. Ice-surface elevation map

relationships (Robinson, 1964 ). Velocity was found to increase from $500-700 \mathrm{~m}$. $/ \mathrm{sec}$. at the surface to about $3,900 \mathrm{~m}$./sec. at a depth of $250 \mathrm{~m}$. Below this depth a slight velocity decrease results from a temperature gradient which is positive downward. A $\pm 40 \mathrm{~m}$. accuracy estimate for ice-thickness values determined from reflections is based upon uncertainty about average seismic velocity below $250 \mathrm{~m}$.

Additional ice-thickness detail was obtained from free-air gravity anomalies calculated for all major and minor stations. Calculations were based upon empirical relationships between changes in gravity and variations in subglacial rock elevation (Bentley, r962; Robinson, 1964). Relative profiles calculated from gravimetric data were adjusted to seismic control points at major stations. Results of the elevation, seismic and gravimetric surveys are shown in Figures 3, 4, 5 and 6. 


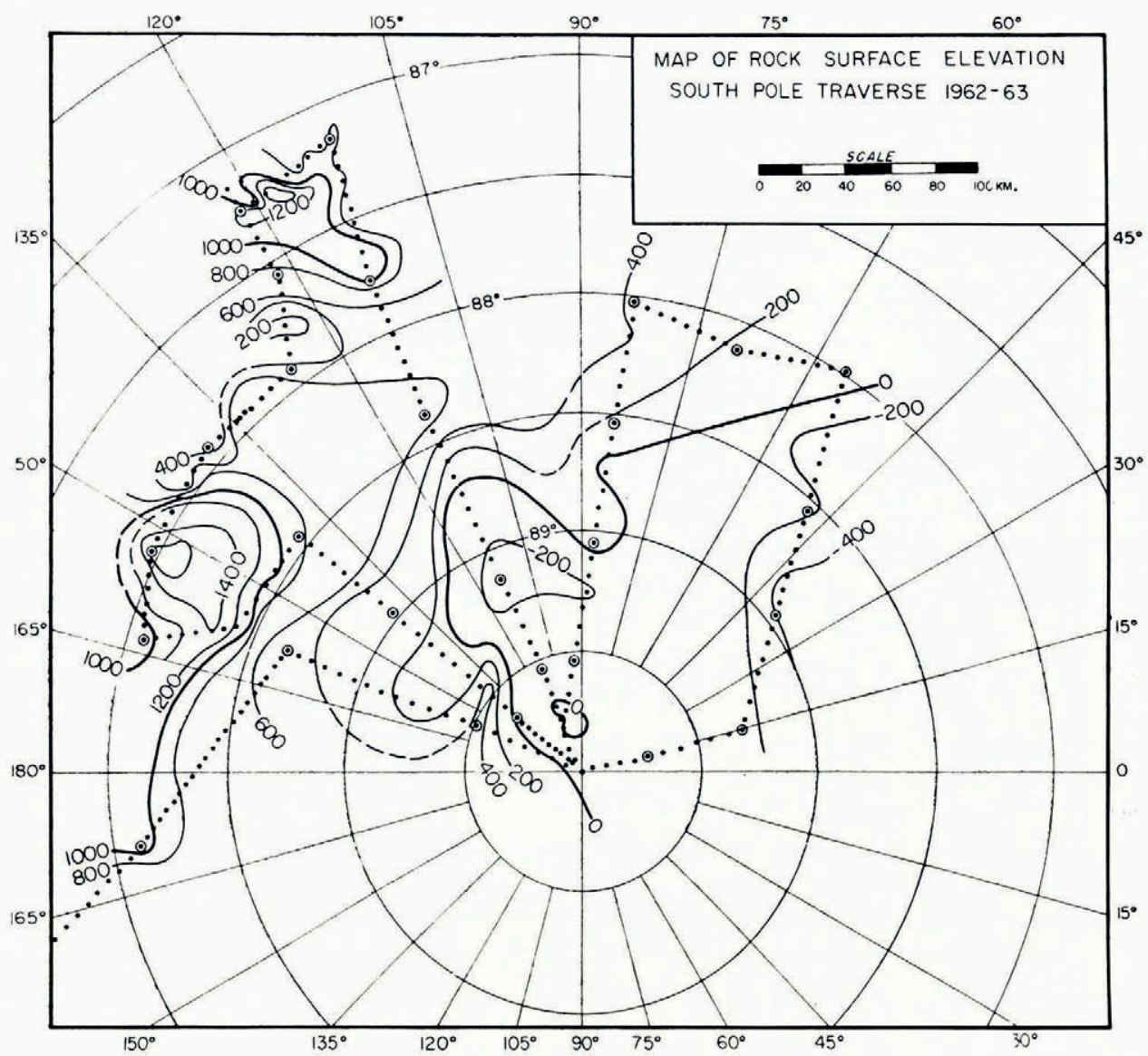

Fig. 5. Rock-surface elevation map

\section{Relationships between Ice-surface and Bed Topography}

Relationships between areal variations in ice thickness and surface slope, and temporary perturbations of the ice surface have been described theoretically in recent discussions of ice mechanics by Nye (1952, I959[a], [b]) and Weertman (1958). The approximate relationship between surface slope $(\alpha)$, basal shear stress $(\tau)$ and ice thickness $(H)$ is given by

$$
\tau=\rho g H \sin \alpha,
$$

where $\rho$ is the ice density and $g$ is the gravitational acceleration.

Nye (I952) suggested that, since $\tau \approx \mathrm{I} \cdot 0 \pm 0 \cdot 5$ bar, by assuming basal shear stress to be constant, variations in ice thickness could be predicted to a first approximation from surface slope measurements. Nye (I959[a], [b]) later described a method for determining bed 


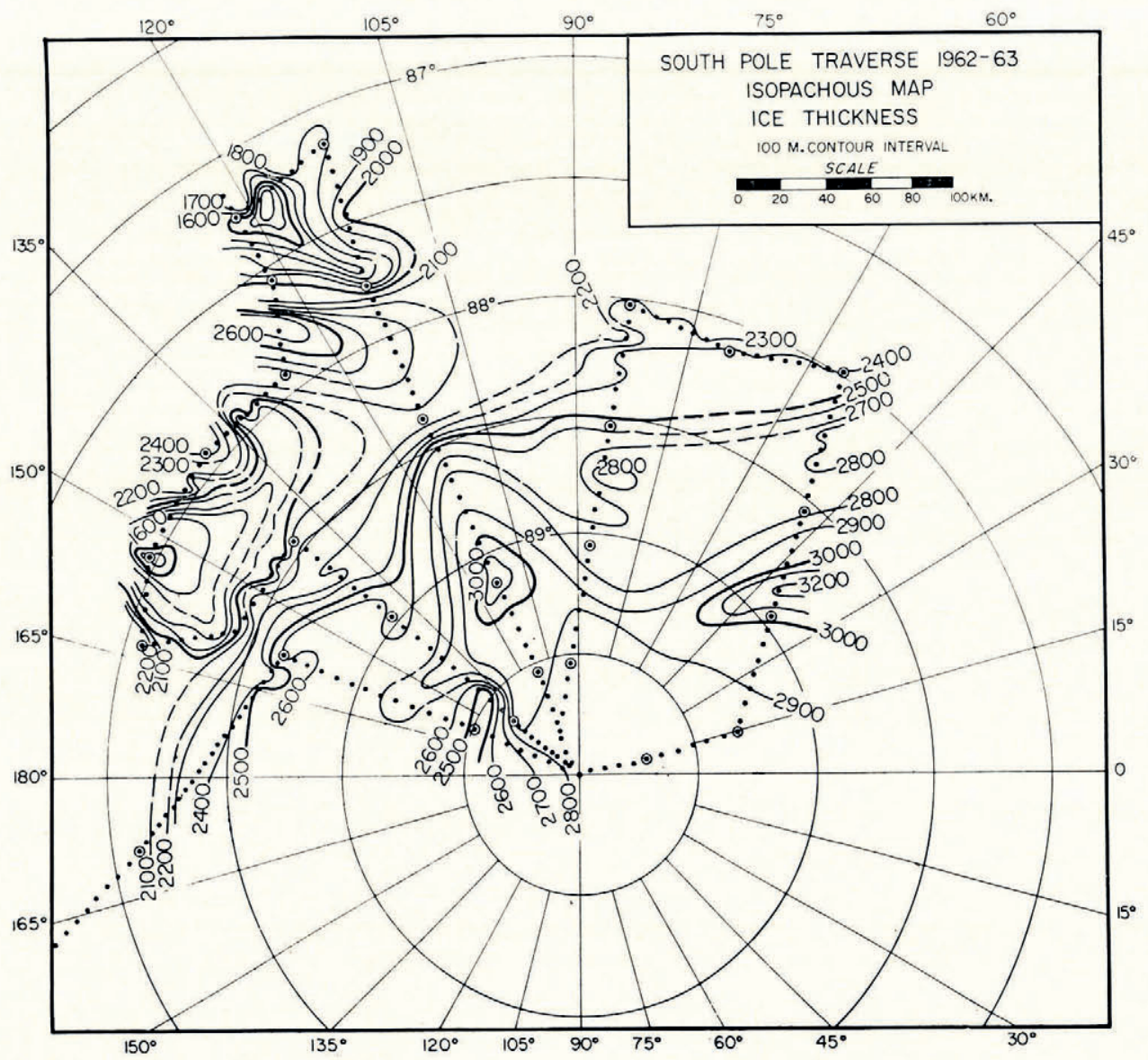

Fig. 6. Ice isopachous map

topography from surface slope variations for situations where basal shear stress was not necessarily constant. He showed that, if an undulation on the surface is to exist for an indefinite period of time, its relationship to bed topography is given approximately by the expression

$$
\frac{\Delta \alpha}{\alpha}=\frac{(m+\mathrm{I}) P}{m H} \approx \mathrm{I} \cdot 4 \frac{P}{H},
$$

where $H$ is the regional ice thickness, $P \ll H$ is the amplitude of the topographic feature on the bed causing a change from regional surface slope of $\Delta \alpha . m$ is a constant related to the flow law for ice (Glen, 1955), and is found from experimental studies to have a value of $2-2 \cdot 5$. 
Surface undulations which are not related to bed topography represent departures from steady-state ice thickness according to formulae derived by Weertman (1958). If $h \ll H$, $\frac{\partial h}{\partial x} \ll Q, \frac{\partial h}{\partial x} \ll \alpha$, and $\frac{\partial h^{2}}{\partial x^{2}} \ll \frac{\partial \alpha}{\partial x}$, where $h$ is a small departure from $H, Q=\alpha-\beta$ where $\beta$ is bed slope, the characteristic decay time $t$ required for $h$ to decay to a small amplitude is

$$
t=\left(B+\frac{4 \pi^{2} D}{\lambda^{2}}\right)^{-1}
$$

where $B=(m+\mathrm{I})(Q U+a) / H, D=m U H / \alpha, U$ is velocity of glacier movement over the bed, $a$ is surface accumulation and $\lambda$ is wave-length of the perturbation. On the basis of these expressions, Nye (1959[a], [b]) suggested that surface undulations on the South Polar plateau reported by members of the Commonwealth Trans-Antarctic Expedition probably represented bed relief of considerable magnitude.

Experimental verification of these relationships was sought from data collected on the traverse during the $1962-63$ season. At 14 major stations the azimuth of maximum surface slope was determined from theodolite observations of horizon elevation. Accurate measurements could not be made at the remaining stations. Magnitude of slope was then calculated from detailed elevation profiles extending a few kilometers to either side of the station. From these slope measurements (Table I) and corresponding ice-thickness values, basal shear-stress

Table I. Values of Local. Shear Stress

\begin{tabular}{|c|c|c|c|c|}
\hline Station & $\begin{array}{c}\text { Surface slope } \\
\text { degrees }\end{array}$ & $\begin{array}{l}\text { Azimuth } \\
\text { degrees }\end{array}$ & $\begin{array}{c}\text { Ice thickness } \\
\mathrm{m} .\end{array}$ & $\begin{array}{c}\text { Shear stres. } \\
\text { bar }\end{array}$ \\
\hline 115 & saddle & - & 2920 & - \\
\hline I1 6 & saddle & - & 2560 & - \\
\hline 117 & 0.4 & 105 & $215^{\circ}$ & $1 \cdot 3$ \\
\hline 118 & $0 \cdot 1$ & - & 2250 & $0 \cdot 1$ \\
\hline 119 & 0.5 & $6 o$ & 1380 & $I \cdot I$ \\
\hline 120 & trough & o & 2460 & - \\
\hline 121 & $0 \cdot 3$ & 30 & 2280 & $I \cdot 1$ \\
\hline 122 & 0.2 & 330 & 2020 & 0.6 \\
\hline 123 & 0.2 & 330 & 1420 & 0.4 \\
\hline 124 & 0.2 & o & 1780 & 0.6 \\
\hline 125 & 0.2 & 30 & 1780 & 0.6 \\
\hline I 26 & ? & 90 & 2190 & - \\
\hline 127 & saddle & $N * S$ & $3^{180}$ & - \\
\hline 128 & negligible & - & $295^{\circ}$ & - \\
\hline 129 & under $\mathbf{O} \cdot \mathbf{I}$ & o & 2850 & 0.2 \\
\hline 1.30 & $?$ & $9^{\circ}$ & 2710 & - \\
\hline 131 & variable & - & $253^{\circ}$ & 0.2 \\
\hline 132 & 0.2 & o & 2310 & 0.7 \\
\hline 133 & trough & 30 & 2460 & - \\
\hline I 34 & 0.4 & $6 o$ & $239^{\circ}$ & $1 \cdot 5$ \\
\hline 135 & 0.4 & $100-150$ & $279^{\circ}$ & $1 \cdot 7$ \\
\hline${ }_{1} 36$ & 0.3 & $33^{\circ}$ & 3040 & $1 \cdot 4$ \\
\hline 137 & variable & - & 2860 & - \\
\hline${ }_{1} 3^{8}$ & variable & - & 2800 & - \\
\hline
\end{tabular}


values were calculated using equation (I). A mean value of 0.8 bar with an areal standard deviation of 0.5 bar was obtained. Local values of ice thickness are plotted against surface slope in Figure 7. It can be seen from this figure that local variations in basal shear stress are sufficiently large to preclude a reasonable estimation of local ice-thickness variation from surface-slope data alone in this area.

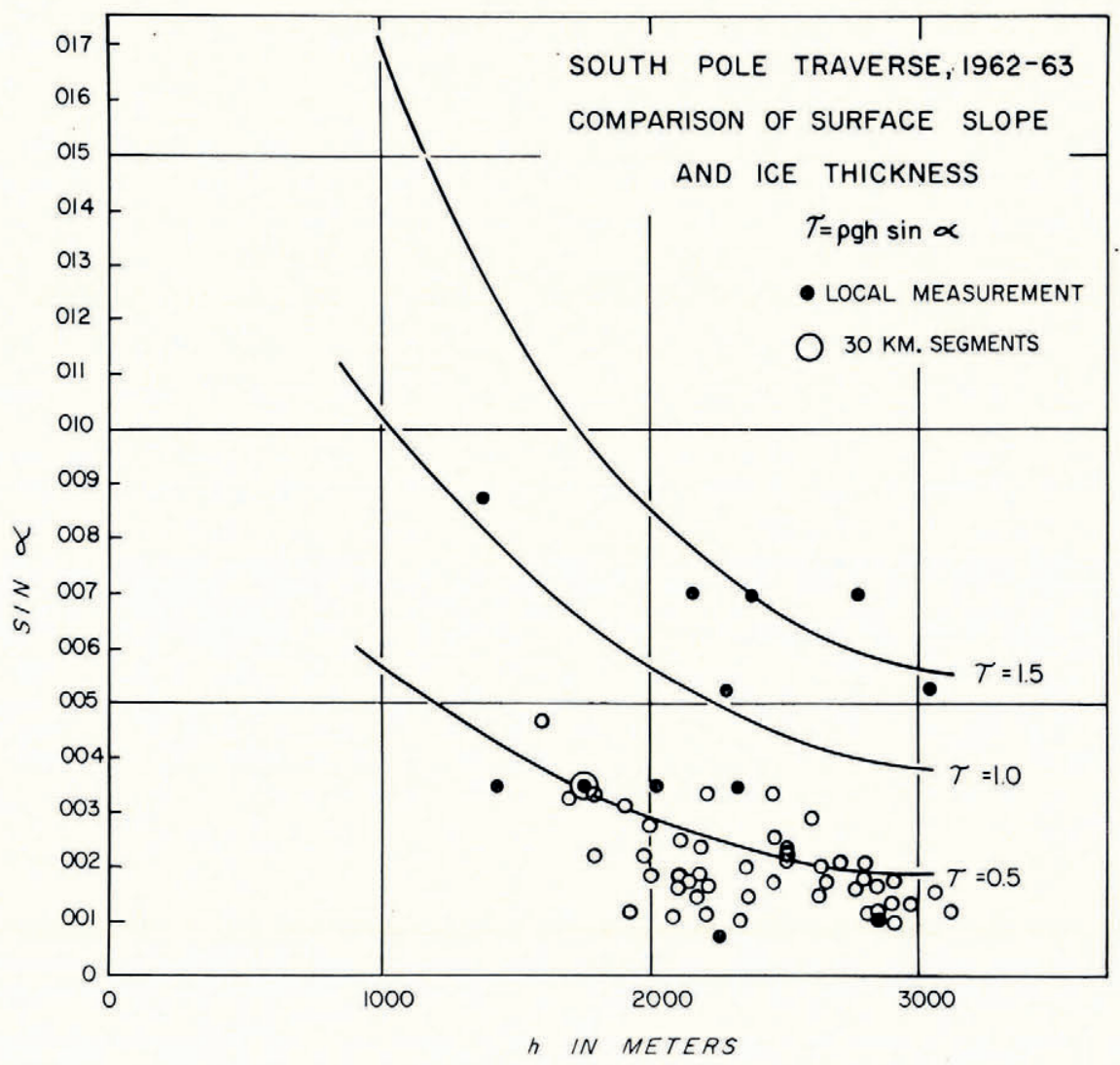

Fig. 7. Comparison of local surface slope and ice thickness

Figure 8 shows detailed surface-elevation profiles compared with bed profiles for the purpose of ascertaining relationships between surface features and bed topography. Although a number of surface undulations appear to be qualitatively related to bed relief, in general the relationship between such relief and change in surface slope is in large disagreement with that expected from equation (2). For example, near station I I5 (Fig. 8) a $400 \mathrm{~m}$. bed rise corresponds to a $30 \mathrm{~m}$. surface rise. The observed ratio $P / H=0.14$ is greatly different from the value of 0.87 predicted by equation (2). Directing attention to the profile extending from the South Pole to station 132 (Fig. 9), where a hypothetical bed profile computed from equation (2) is compared with actual bed relief, there is poor agreement between observed and theoretical relationships. Computation of the hypothetical profile was based upon the true regional 


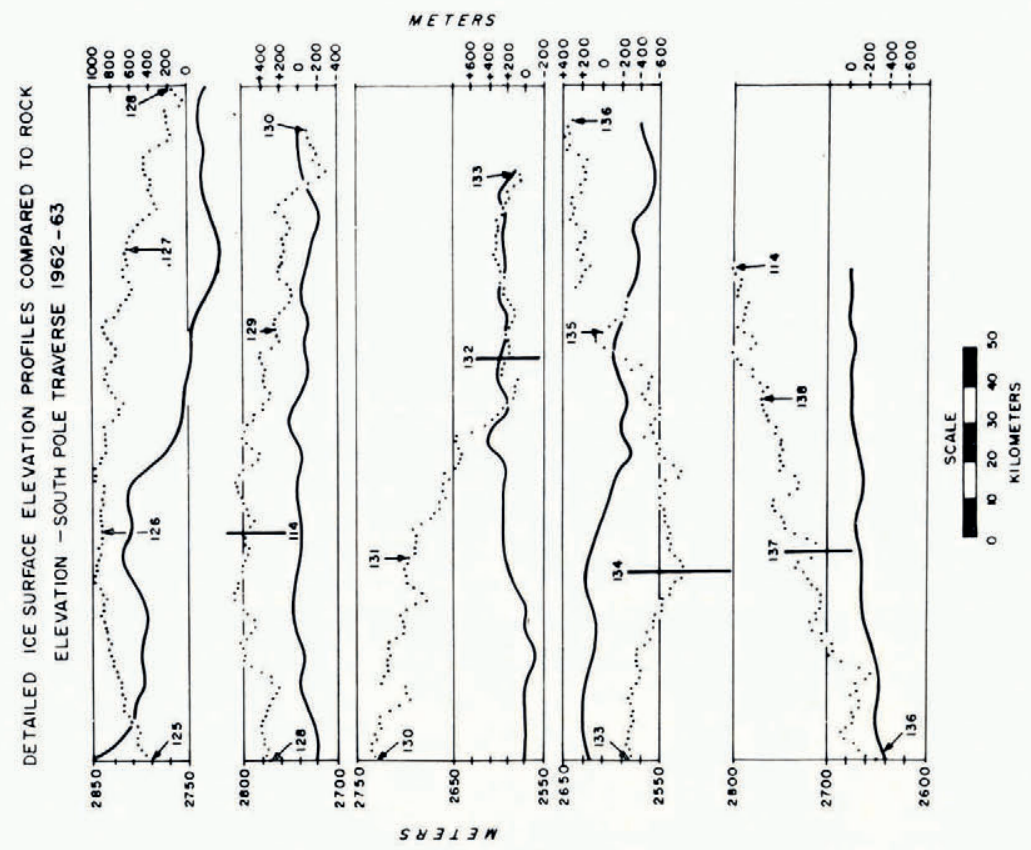

ปัँ

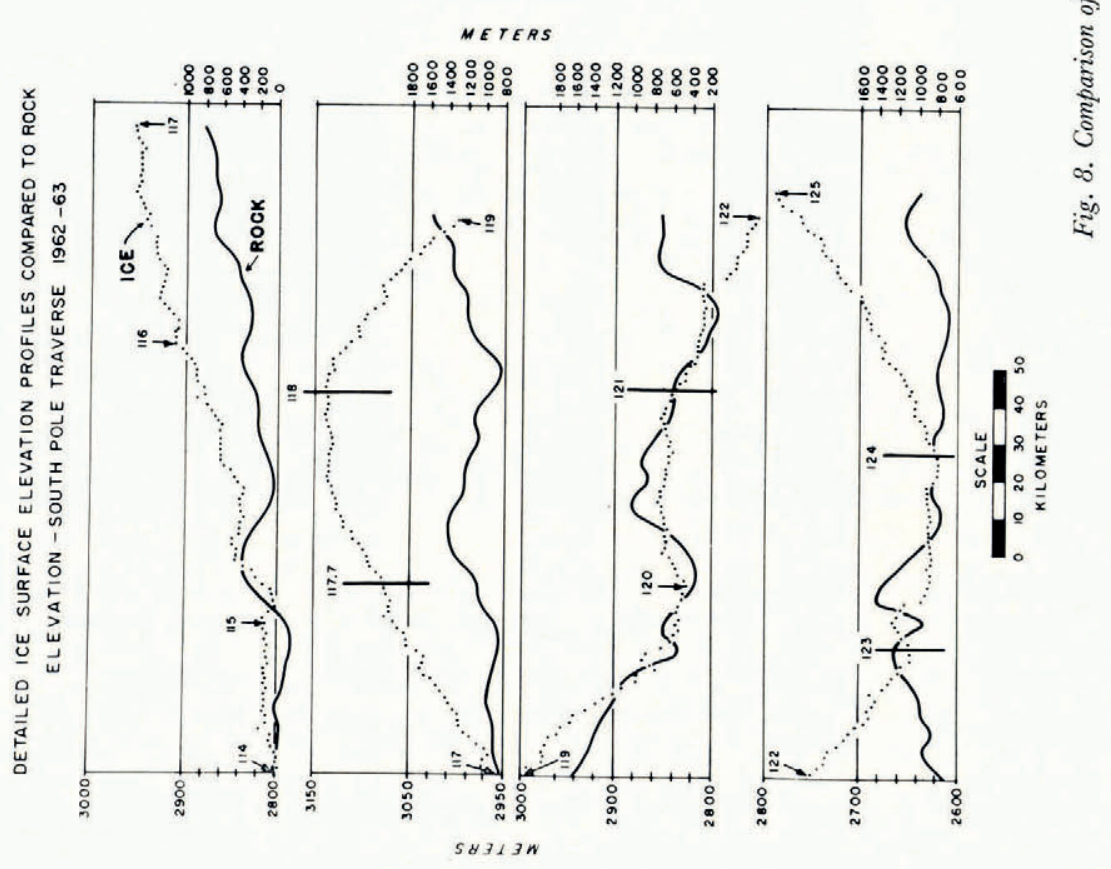




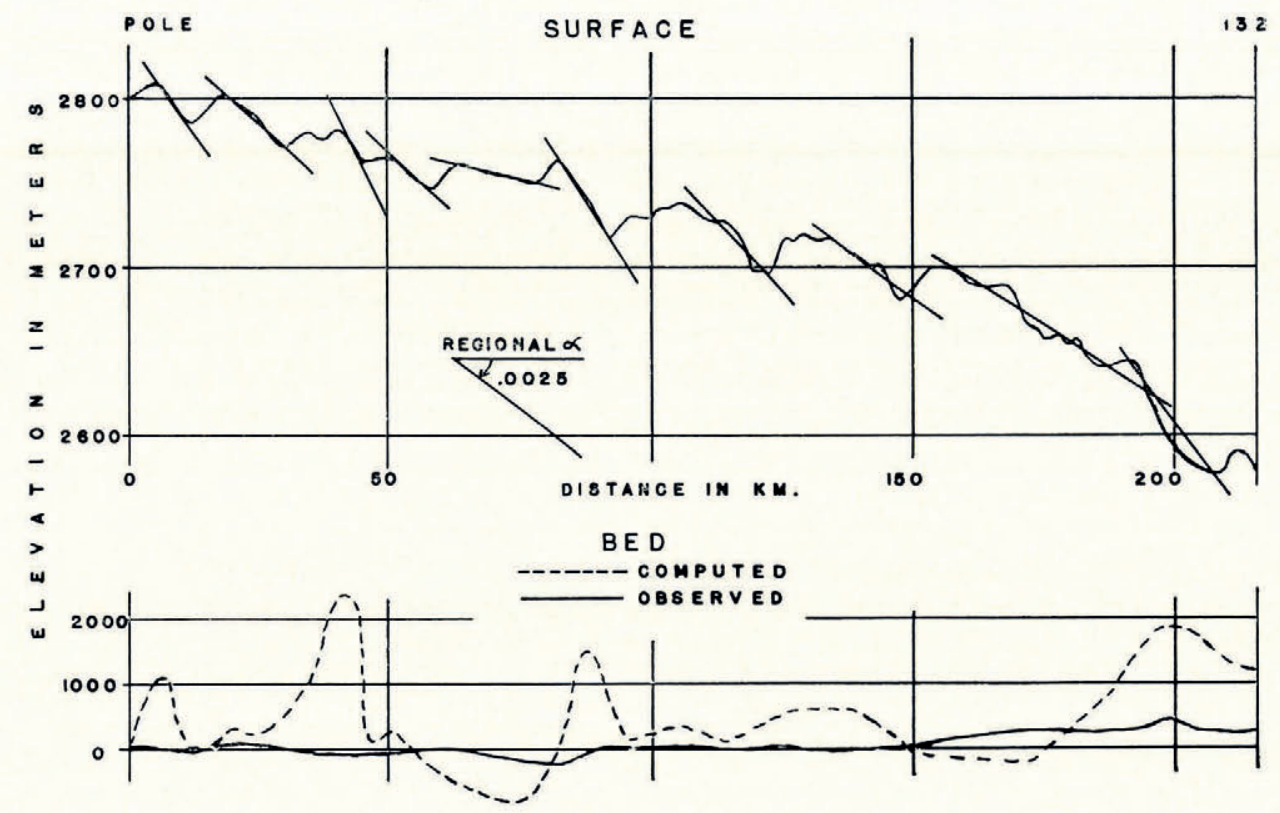

Fig. 9. Profiles from South Pole to station $\mathrm{I}_{32}$ (lat. $88^{\circ}$ or' S., long. $83 \cdot 2^{\circ} \mathrm{W}$.)

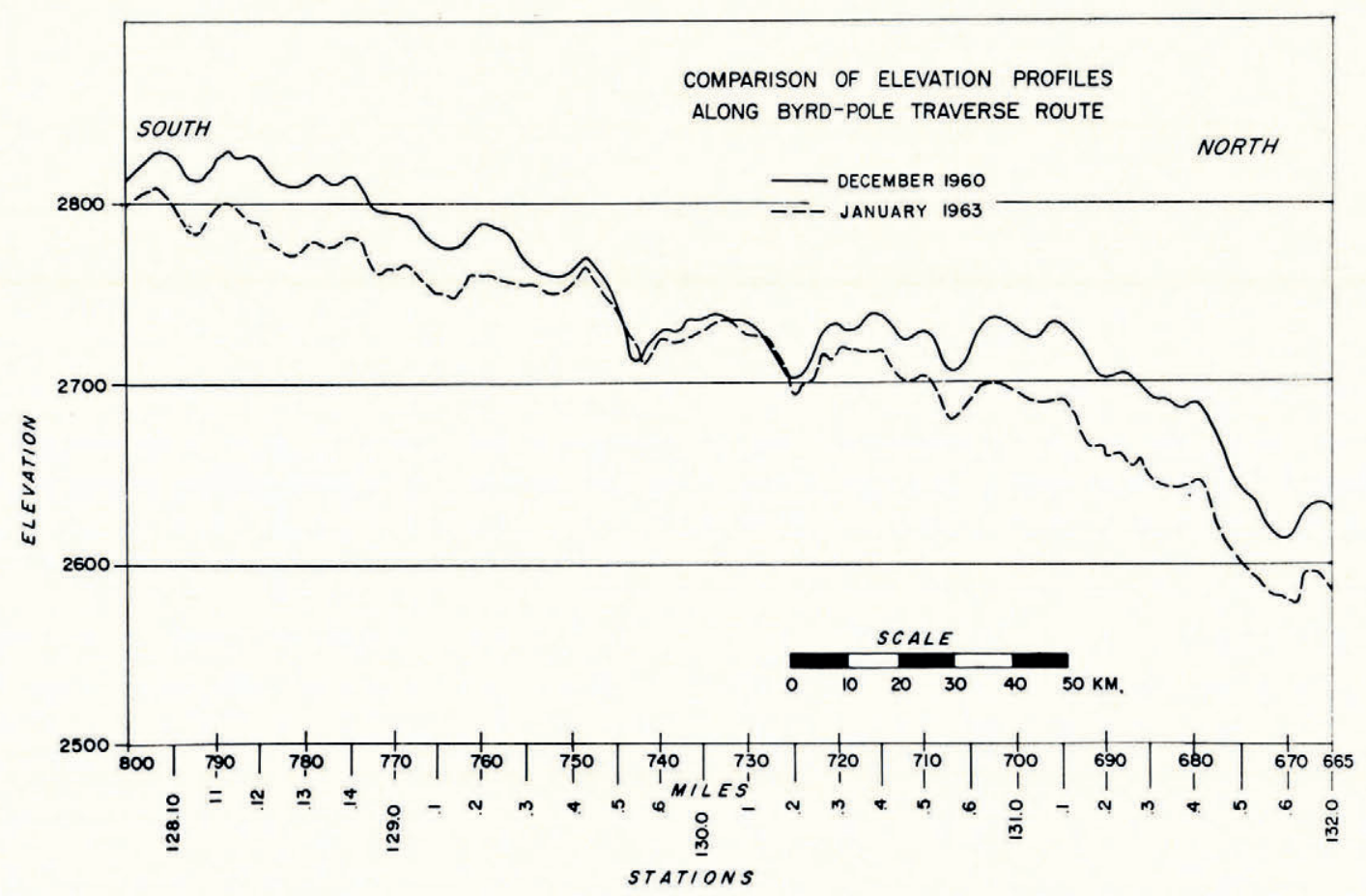

Fig. 1o. Comparison of elevation profiles; South Pole to station $13^{2}$ 
surface slope of $0 \cdot 0025$ rad., measured from Figure 4, and local apparent variations measured from the profile. Calculated bed relief would tend to be minimized since apparent $a$ will be less than, or equal to true $\alpha$. Next, looking at the area near stations II 7, II8, II9 and I20, there is a broad surface rise (Fig. 4) and a broad bedrock rise (Fig. 5). However, the surface dome is offset about $40 \mathrm{~km}$. to the west of the maximum rise of the bed. Hence, the correlation between surface features and bed relief is not explained by equation (2). This suggests that either equation (2) is inadequate to explain the relationship, or that the surface features are not related to bed topography, but instead represent deviations from steady-state ice thickness.

Again directing attention to the profile from the South Pole to station $13^{2}$, there is a series of surface undulations between 10 and $30 \mathrm{~m}$. in amplitude, and from 5 to $35 \mathrm{~km}$. in wavelength. This particular profile was measured on two different occasions: first during December I 960 by the Army-Navy "Byrd" station to South Pole tractor train (personal communication from F. L. Dowling); then during January ${ }_{1} 6_{3} 3$ by the traverse party. Observation points at $\mathrm{I} \cdot 5 \mathrm{~km}$. intervals were re-occupied within $0.5 \mathrm{~km}$. The two profiles are compared in Figure Io. Although absolute elevations diverge up to $40 \mathrm{~m}$., as would be expected from changing pressure gradients and random error, the local undulations were found to have the same amplitude, wave-length and position after a period of two years. If velocity of ice movement can be estimated, deviations of this magnitude from steady-state ice thickness might be investigated using equation (3). If it is assumed that velocity of ice movement does not vary with depth, the value can be determined from the expression

$$
U=\frac{a}{w H} \int_{0}^{x} w_{x} d x,
$$

where $w$ is width between two flow lines, and $x$ is the distance from the drainage divide. Considering the area between flow lines 4 and 5 (Fig. 4), the distance $x$ can be measured from the surface dome near station I 8 (Figs. I and 3) which is the apparent local divide. The average accumulation is $8.5 \mathrm{~cm}$. $/ \mathrm{yr}$. For these values, the estimated velocity at station $\mathrm{I} 3 \mathrm{O}$ is $3 \mathrm{~m}$./yr. If ice flow were related to a major divide much farther away, a higher velocity

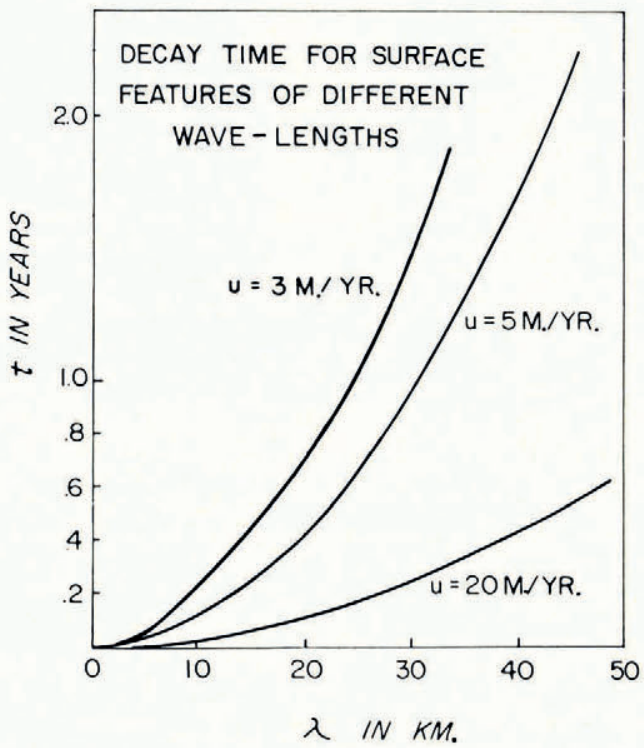

Fig. II. Decay times for surface features 
would be required. The decay times for features of different wave-lengths for three possible velocities, 3, 5 and $20 \mathrm{~m}$./yr., can be obtained from Figure I I, which is based on equation (3). The undulations in Figure ro would not be expected to last more than one year if they represented deviations from the steady-state. Since the data show little or no change over a two-year period, the results of equations (2) and (3) are contradictory.

Part of the failure to obtain good agreement between theory and observation may reflect uncertainty in ice-thickness and elevation data, and possible presence of topography undetected by the profiles. Another contributing factor may be an ice sheet not at present in equilibrium. Ice regime studies by Giovinetto and others (1966) indicate that the area to the north, which borders the Ross Ice Shelf, may have a positive budget. If the area between flow lines 4 and 5 were characterized by a net positive budget, the calculated velocity of $3 \mathrm{~m}$. $/ \mathrm{yr}$. would be too great, and unstable surface features might be expected to persist for longer periods of time. Temperature considerations based upon equations presented by Robin (1955) and Weertman (I96I) suggest that the ice may be locally frozen to the bed. If such were the case, movement might be irregular, dependent upon sufficient build-up of stress to break the ice free. During this build-up temporary deviations from the steady-state could exist for longer periods than indicated by equation (3). From this experimental study it cannot be determined whether one or both of equations (2) and (3) are inadequate to describe the observations. It is clear, however, that in this area surface-slope data alone are insufficient to describe the character of the bed. This study and other similar investigations reported by Bentley ([1964]) and Bull (1957) indicate the difficulty at this time in finding a satisfactory explanation for observed ice-sheet features.

MS. received 16 March 1965

\section{REFERENCES}

Bentley, C. R. 1962. Glacial and subglacial geography of Antarctica. American Geophysical Union. Geophysical Monograph No. 7, p. 9-25.

Bentley, C. R. [1964.] The structure of Antarctica and its ice cover. (In Odishaw, H., ed. Research in geophysics. Vol. 2. Cambridge, Mass., Massachusetts Institute of Technology Press, p. 335-89.)

Bull, C. 1957. Observations in North Greenland relating to theories of the properties of ice. Fournal of Glaciology, Vol. 3 , No. 21, p. $67-72$.

Giovinetto, M. B., and others. 1966. The regime of the western part of the Ross Ice Shelf drainage system, by M. B. Giovinetto, E. S. Robinson and C. W. M. Swithinbank. Fournal of Glaciology, Vol. 6, No. 43, p. 55-67.

Glen, J. W. 1955. The creep of polycrystalline ice. Proceedings of the Royal Society, Ser. A, Vol. 228, No. 1175 , p. 5 19-38.

Nye, J. F. 1952. A method of calculating the thicknesses of the ice-sheets. Nature, Vol. I69, No. 4300, p. 529-30.

Nye, J. F. I 959[a]. The motion of ice sheets and glaciers. Fournal of Glaciology, Vol. 3 , No. 26, p. 493-507.

Nye, J. F. 1959[b]. Surface topography of the Antarctic Ice Sheet. Nature, Vol. 184, No. 4689, p. 786-87.

Robin, G. de Q. 1955. Ice movement and temperature distribution in glaciers and ice sheets. Journal of Glaciology, Vol. 2, No. 18, p. 523-32.

Robinson, E. S. 1964. Some aspects of subglacial geology and glacial mechanics between the South Pole and the Horlick Mountains. University of Wisconsin. Geophysical and Polar Research Center. Research Report 64-7.

Weertman, J. 1958. Traveling waves on glaciers. Union Géodésique et Géophysique Internationale. Association Internationale d'Hydrologie Scientifique. Symposium de Chamonix, $16-24$ sept. 1958 , p. $162-68$.

Weertman, J. 1961 . Mechanism for the formation of inner moraines found near the edge of cold ice caps and ice sheets. Journal of Glaciolog;, Vol. 3 , No. 30, p. 965-78. 